\title{
The Status of Historical Characters in Drama: Ontological, Aesthetic, and Verisimilar
}

\author{
O status dos personagens históricos no drama: Ontológico, Estético e Verisimilar
}

Brian Richardson

University of Maryland - Tawes Hall - Estados Unidos da América $\diamond$

\begin{abstract}
Using the depictions of Niels Bohr and Werner Heisenberg in Frayn's Copenhagen as touchstones, the paper explores the ontological status of historical characters in drama. It argues that fictional characters, whether or not based on historical individuals, inhabit a fictional realm and may, for a number of reasons, diverge considerably from their real world counterparts.
\end{abstract}

Keywords: Historical characters; Drama; Michael Frayn

Resumo: Usando as representações de Niels Bohr e Werner Heisenberg em Frayn's Copenhagen como pedra de toque, o artigo explora o status ontológico de personagens históricos em drama. Ele argumenta que os personagens de ficção, baseados ou não em indivíduos históricos, habitam um reino de ficção e podem, por uma série de razões, divergir consideravelmente de seus homólogos do mundo real.

Palavras-chave: Personagens históricos; Drama; Michael Frayn

Michael Frayn's historical drama, Copenhagen, produced in London in 1998, speculates on what might have transpired during a meeting between physicists Niels Bohr and Werner Heisenberg in Copenhagen in September 1941, a meeting at which the atomic bomb might have been discussed. The play has generated impassioned debates concerning the accuracy of the depictions of the historical figures. Frayn himself affirmed the play's general fidelity to the historical events and personalities it in a lengthy postscript to the work in which he also indicates the points at which his speculations went beyond the historical record. Concerning the invention of dialogue for scenes that were unrecorded, he refers to Heisenberg's own defense of this practice when reconstructing conversations in his personal memoir. The physicist cited the example of Thucydides as a model: in the case of conversations far in the past, "I have found it impossible to remember their exact wording. Hence I have made each orator speak as, in my opinion, he would have done in the circumstances, but keeping as close as I could to the train of thought that guided his actual speech" (96-97).

Such good intentions proved to be insufficient. Unsurprisingly, not everyone was convinced of the play's accuracy. Historian Paul Lawrence Rose, who had written a book on Nazi attempts to build an atomic bomb, denounced the play. Though he acknowledged the dramatic power of the work, "the price we pay for the dramatic thrill Frayn has concocted - the sacrifice of historical and scientific truth-is simply too great. [...] Frayn perverts the moral significance of the meeting as well as distorting and suppressing its scientific and political agenda." Many others have also commented on the work's historical material; these include historians, literary theorists, drama critics, and physicists. ${ }^{1}$

Such responses themselves raise larger theoretical questions, specifically what is the nature of historical representation in literature and what does it mean to represent or misrepresent a historical personage on stage? At what point do we say of a personage, that that's not Einstein or Heisenberg, and, more importantly, what are the implications of such a claim? We may begin with some general comments on the nature of characterization. In an article published some years ago I argued (as had James Phelan) that characterization involved three fundamentally different components: I call these a mimetic drive that seeks to present typical or actual

\footnotetext{
1 See for example the accounts online at Complete Review: $<$ http://www complete-review.com/reviews/fraynm/cophagen.htm>.
} 
persons or person-like entities, an ideological component that treats characters as instances of competing ideological positions, and an aesthetic design that produces a narrative economy and aesthetic symmetry among the actions of the figures on the stage. In enacted narratives, there may also be a performance component that further adds to characterization.

Thus, in Shakespeare's 1 Henry $I V$, the character of Hotspur can be compared to historical accounts of the actual Henry Percy. We find however that he was in fact older than King Henry IV, Prince Hal's father, and was certainly less colorful and less honor-driven than Shakespeare's version of the man. His ostensible ideological function is to dramatize the folly of impetuosity that is untempered by wisdom while the deeper ideological thrust shows the uncomfortable parallels between the rebel leader and the sitting king, who had deposed his predecessor, Richard III. The main aesthetic function of this figure is to provide, through an elaborate system of parallels and oppositions, a suitable foil for his double and rival, Prince Hal. Indeed, Shakespeare no doubt changed the age of his Hotspur and made him many years younger not because he was confused about the historical facts but to produce more effectively this aesthetic and thematic pairing of comparable opposites. We might also note that the scene in which Falstaff pretends to be King Henry scolding Hal probably occupies exactly the same stage space as the later scene in which the king does scold his son. Such parallel scenes produce a kind of "visual rhyme" that inflects the later event, making the king's figure seem considerably less royal (see Rose). ${ }^{2}$ These are the kinds of interpenetrating concerns we need to bear in mind when discussing any characterization, historical or otherwise.

August Strindberg's historical dramas are often at considerable variance from the facts of history; his play Gustav III is almost as reminiscent of Shakespeare's Richard II as it is of biographical depictions of the Swedish king. Still more wayward is his misogynistic depiction of the monarch in his play Queen Christina, about Sweden's $17^{\text {th }}$ century lesbian queen, a figure about whom Strindberg felt extreme fascination and repulsion. "Christina was so genuine a woman that she was a woman hater," he wrote in his Open Letters to the Intimate Theater (3). This gives a fair view of the nature of Strindberg's artistic detachment. Forty years ago, the life of Queen Christina was again performed on stage, this time in Pam Gems' play. Though it covers much of the same territory it is perhaps equally inaccurate, setting forth a character that sounds much more like an early

\footnotetext{
2 Furthermore, when a single actor portrays two characters, as when King Duncan is played by the same one who represents Macduff, such characterological conflation may be even more pronounced (see Booth).
}

1970 's feminist than a figure from the $17^{\text {th }}$ century. In both plays, ideological concerns overwhelm mimetic pretensions.

In what many might consider an exquisite act of literary revenge on the playwright who so thoroughly violated the known facts of the historical figures he depicted, modern Swedish author Per Olov Enquist constructed a play about the historical Strindberg, his estranged wife, Siri von Essen, and her lesbian lover, Marie Caroline David. The play, The Night of the Tribades, centers on a difficult rehearsal of Strindberg's short play, "The Stronger," which the three were in fact mounting in 1889 in Copenhagen. Enquist drew extensively on Strindberg's writings, especially his autobiographical volume, A Madman's Defense, as well as - most interestingly for this analysis - Strindberg's partially autobiographical play, The Father. After the play opened in 1973, criticism was intense over the accuracy of the portrayal of the historical Strindberg; extremely old men who had known the playwright wrote letters to newspapers claiming that Strindberg they were acquainted with was not at all like the figure in the play. Based on my own knowledge of the character of the historical Strindberg, I tend to agree with the old men. The actual Strindberg was more ambitious, powerful, overeaching, and audacious than the frustrated, hamstrung, neurotic figure created by Enquist. When confronted by these charges, the modern playwright made the interesting but revealing claim that he was not attempting to portray the historical Strindberg but rather his personal conception of Strindberg. I would say that the play-and it is a very good play - attains its aesthetic balance and ideological effectiveness in a contemporary era precisely by eliding historical accuracy.

Another paradoxical example suggests itself at this point. Jean Anouilh narrates the story of his finding a copy of Augustin Thierry's History of the Norman Conquest of England; he was especially impressed by the chapter on the struggle between Thomas Becket, the Saxon Archbishop of Canterbury and his AngloNorman antagonist, King Henry II. He rapidly turned the material into a play, Becket, and gave it to a historian to read. Later, when they met again, the historian roared with laughter and informed him that for over fifty years they had had proof that Becket was not a Saxon but a good Norman who came from Rouen and was called "Bequet." Since a large part of drama revolves around Becket being of the vanquished ethnicity, the play would have had to be entirely rewritten for it to be accurate at all. But Anouilh had grown to like the structure and development of his story even more than its pretensions to historical verisimilitude; "for this drama it was a thousand times better that Becket remained a Saxon," he wrote. "I 
changed nothing; I had the play performed three months later in Paris. It was a great success and I noticed that no one except my historian friend was aware of the progress of history" (vii-viii).

Matthew Wikander, in his study of the subject, observes that "creating great historical drama is a tightrope act; the strain of balancing the warring demands of dramatic form and historical data soon begins to tell" (238). We may go still further and state that in the historical dramas by Shakespeare, Strindberg, Gems, Enquist, and Anouilh we find an unresolvable tension between unquestioned historical facts and theatrically effective narrative depictions; the successful playwright invariably betrays the former to serve the latter.

Let us return to these and related issues raised by Frayn's characterizations: first of all, the figures are clearly fictional; the scene is set after they are all dead. Furthermore, Frayn acknowledged altering the characters somewhat in the service of a more compelling drama. Niels Bohr, for instance, "was as notorious for his inarticulacy and inaudibility as he was famous for his goodness and lovability" (103); the first two characteristics had to be jettisoned for the play to be successfully performed. Frayn admits to probably slandering Bohr's wife, again in the interests of effective drama: "I suspect she was more gracious and reserved than she appears here" (103). And "the problem with Heisenberg was his elusiveness and ambiguity" (104); Frayn had to partially construct a recognizable character for him out of the indeterminate historical materials that he consulted.

Most significantly, in Copenhagen, many different aspects of Heisenberg's character are set forth, and numerous possible motives are explored. But one indisputable facet of his actual character has wisely been left out: his deep nationalism and affinity for many of the same Romantic causes and topoi that the Nazis also enjoyed. Given the type of play Frayn decided to write, these options, however historically accurate they may have been, could not be presented on stage. A zealously nationalistic Heisenberg, who felt Germany's bellicosity was understandable and who was confident about its ultimate victory would not work; in all probability, it would be booed off the stage, and rightly so. To reiterate, once Frayn decided on the type of drama he would construct, a number of genuine historical possibilities ceased to be available to him as a playwright.

And we may ask ourselves the question posed most dramatically by Anouilh: what should Frayn do if, when all of Bohr's and Heisenberg's letters and papers are finally made public, it turns out that his characterization of Heisenberg is all wrong? The author may well feel no need to rewrite his successful play; he could claim that this is a set of possible events, rather than actual ones, or, perhaps ingenuously, that it is an accurate representation of the historical situation as understood at the time of its writing. Or he could simply say that this is what his Bohr and his Heisenberg are; if they diverge from history, then so be it.

This conclusion raises two seemingly contradictory responses. Looking at the conceptually larger issue of the ontological status of fictional characters, we find there is no insistent and unambiguous referential claim to be made. Nonfictional works are falsifiable in a way that fiction cannot be. If we read in a biography that Napoleon died in 1805 or 1851 , we know that statement is false since all other accounts indicate he died in 1821. In a work of fiction, he can die in any year, and be as bold or timid as the author wants him to be (or henpecked, as George Bernard Shaw presents him in "The Man of Destiny"). ${ }^{3}$ Similarly, while new historical discoveries may have to be taken into consideration, no statement from a work of fiction can require us rework any biographical treatment account.

Marie-Laure Ryan asks how "can the imaginary Natasha in War and Peace lose her fiancé in a war against a historical Napoleon?" She then explains that "the attribute of fictionality does not apply to individual entities, but to entire semantic domains: the Napoleon of War and Peace is fictional because he belongs to a world which as a whole is fictional" (15). Similarly, Anna Whiteside points out in her summary of philosophical theories of reference, "when Stendhal refers to Napoleon, Baudelaire to Paris, Chekhov to Moscow, ... however realist or naturalist their art, they refer not so much to the extratextual primary referent mentioned but to their own highly connoted intertextual and intratextual literary artifact" (179). In short, there is no actual ontological commitment in literary works; they cannot be falsified the way a work of nonfiction (including documentaries) can be. The creative author can always legitimately say "Well, that's just my idea of the person" in a way that biographers can't when confronted with overwhelming evidence that contradicts their claims. Thus, even in the representation of historical individuals, there is a fundamental poetic license that sets the work apart from nonfictional accounts. In the words of Lubomir Doležel,

\footnotetext{
3 In his preface to Saint Joan, a quasi-historical drama with numerous anachronisms, Shaw declared that "it is the business of the stage to make its figures more intelligible to themselves than they would be in real life"; in order to provide "sufficient veracity," he had to incur a "sacrifice of verisimilitude" and make his characters say "the things they actually would have said if they had known what they were really doing" (52-53). These lines and Shaw's play are discussed in Hernadi, 17 and $19-30$.
} 
"As nonactualized possibles, all fictional entities are of the same ontological nature. Tolstoy's Napoleon is no less fictional than his Pierre Bezuchov, and Dickens' London is no more actual than Carroll's Wonderland" (18). He goes on to explain that "actual-world (historical) individuals are able to enter a fictional world only if they become possible counterparts, shaped in any way the fiction maker chooses" (21); thus, "the actual Napoleon can be transformed into an unlimited number of alternate [fictional] incarnations, some of them differing essentially from the actual world prototype" (225). ${ }^{4}$

We see this kind of transformation (and its retraction) in Tom Stoppard's postmodern documentary television film, Squaring the Circle, an account of the Solidarity labor movement in Poland that was made without the necessary historical materials being available at the time of the work's composition. Stoppard deals with this limitation in a playful manner. As the camera reveals Polish leader Gierek, dressed in a suit, hat, and overcoat, walking on a beach, the narrator states: "Towards the end of July 1980 Edward Gierek, First Secretary of the Polish United Workers' Party, which is to say the boss of Communist Poland, left Warsaw for his annual holiday in the Soviet Union by the Black Sea. There he met [...] Leonid Brezhnev, First Secretary of the Communist Party of the USSR" (21). Brezhnev, similarly dressed, walks toward Gierek. The two exchange stilted greetings in the official phraseology of the Communist Party, until the narrator comments: "That isn't them, of course," and speaking into the camera, adds, "and this isn't the Black Sea. Everything is true except the words and the pictures. If there was a beach, Brezhnev and Gierek probably didn't talk on it, and if they did, they probably wouldn't have been wearing, on a beach in July, those hats and coats and lace up shoes" (21-22).

The scene now changes, revealing cheery umbrellas and brightly colored drinks, "Brezhnev and Gierek are now wearing brightly coloured Hawaiian shirts and slacks. They wear sunglasses. They drink from pink drinks with little purple paper umbrellas sticking out of them" (22). This time, Brezhnev talks like a gangster in a Hollywood movie: "What the hell is going on with you guys?" (22).

\footnotetext{
4 Bohumil Fořt similarly affirms there is "an essential difference between fictional and historical entities - in spite of the fact that they both arrive via semiotic channels and therefore can be viewed as mere possible counterparts of real people" (55). He goes on to state that "fictional entities simply do not refer to actual entities, nor do they refer across the ontological border between fictional and actual worlds" (56). He goes on to cite Thomas Pavel on this point: "Hamlet, Anna Karenina, Sherlock Holmes, Macbeth's dagger, Des Esseintes' mansion, Proust's madeleine, are constantly talked about both by literary critics and by ordinary readers as if these characters and objects were fully individuated and, in some unspecified way, as if they empirically existed. At the same time, names like Anna Karenina and definite descriptions like Proust's madeleine do not denote in our world" (31).
}

After a bit more of this kind of speech, the scene changes again. The beach is now deserted and the narrator states: "Who knows? All the same, there was something going on which remains true even when the words and pictures are mostly made up" (22-23).

Stoppard is thus giving a number of demonstrably incorrect versions of an actual historical event, thereby demonstrating the ontological independence of any (and every) narrative presented as a work of fiction, including historical fiction. At the same time, he points to a real set of events that generated his literary attempts even as he acknowledges the limitations of our historical knowledge on this and related points. As he explains in the introduction to the work, a central problem was to determine the actual character of Poland's leader at the time, General Jaruzelski, a question on which there were several different positions. "Some saw him as a hard liner, Moscow's Man; others saw him as a 'patriot' forced into a tough Polish solution to stave off a tougher Russian one. We tended to think of him as a 'moderate.' I recall that the judgement was based on one concrete fact that kept cropping up in the research material: Jaruzelski, as Minister of Defense, had once refused to order Polish soldiers to fire on Polish workers" (8). Stoppard goes on to note that two years later, after the film was completed, he "learned that new information tended to consign the 'fact' to myth" (8).

Now that the ontological issue seems to be settled - that every character in fiction, whether invented or historical, is equally fictional-we may go on to ask what then does it mean for an author to strive for and even succeed in accurately depicting historical characters? Here we may turn to Dorrit Cohn: "when we speak of the nonreferentiality of fiction, we do not mean that it cannot [correspond] to the world outside the text, but that it need not refer to it" (78). There may be a correspondence, or there may not be one. This is not to say that authors should not attempt to be as accurate as possible, and that the audience should not value such accuracies, but only that the full range of issues involved are multivalenced and, as we have seen, often mutually exclusive. Truth and beauty are not one. As any producer will tell you, it's no good to have a perfectly accurate historical play if none of the spectators will stay around for the second act. But this is perhaps only to reiterate that the mimetic is only one of the three mainsprings of characterization, and that even here, as Aristotle noted, history occupies a substantially different order of discourse than does poetry or literature. Despite the fact that it can seem to be of extreme importance to many audiences, those who insist on the importance of accurate representations can always be answered with the phrase, 
"But it's only a play (or a novel); if you want fidelity to what happened in all its detail and complexity, read the historians." 5

I wish to articulate one final caveat concerning historical representation: in the act of reception, it is usually impossible to entirely bracket one's historical knowledge. In the case of a sympathetic portrait of Hitler or Stalin, the fictional figure is contaminated by what we might call "the stain of the real," as our psychological response is at variance with logical principles. Such a portrait of a ruthless historical dictator will naturally seem to whitewash some of their crimes, and thus is worthy of censure, but ontologically (and only ontologically) any avowedly fictional description, whether close to or distant from the historical record, positive or negative, parodic or postmodern, belongs to a possible fictional world, not the one we inhabit. A fictional portrait will never change the facts about a historical individual, and judgments about the former are logically irrelevant to the evaluation of the latter (though of course the uninformed may be led into false judgments by assuming the fictional portrait is credible).

To conclude our discussion of this most slippery subject, we may affirm that ontologically speaking, fictional characters, whether or not based on historical individuals, inhabit a fictional realm and may diverge considerably from their real world counterparts. From the perspective of verisimilitude, we may affirm or deny to proximity of resemblance between fictional and historical versions of an individual. Aesthetically, we should assume that a number of distortions of the historical record are committed in order to provide a better narrative; poetic license demands a certain degree of historical elision and fabrication. Psychologically, we cannot always fully treat historical characters as mere fictional creations: certain historical resonances are impossible to erase. Even in a genre largely defined by its mimetic component, we see that aesthetic, ideological, and theatrical aspects play a significant role in the representation of historical characters.

\section{References}

JEAN, Anouilh. Beckett, or the Honor of God, trans. Lucienne Hill, New York: Signet, 1960.
BOOTH, Stephen. Speculations of Doubling in Shakespeare's Plays. Shakespeare: The Theatrical Dimension. Ed. Philip C. McGuire, David A. Samuelson AMS, 1979.

COHN, Dorrit. The Distinction of Fiction. Johns Hopkins UP, 1999.

DOLEŽEL, Lubomir. Heterocosmica: Fiction and Possible Worlds. Johns Hopkins UP, 1998.

FOŘT, Bohumil. An Introduction to Fictional Worlds Theory. Frankfurt: Lang, 2016.

FRAYN, Michael. Copenhagen. Random, 2000.

HERNADI, Paul. Interpreting Events: Tragicomedies of History on the Modern Stage. Cornell UP, 1985.

PHELAN, James. Reading People, Reading Plots: Character, Progression, and the Interpretation of Narrative, Chicago: U of Chicago P, 1989.

PAVEL, Thomas. Fictional Worlds. Cambridge: Harvard UP, 1986.

RICHARDSON, Brian. Beyond Poststructuralism: Theory of Character, the Personae of Modern Drama, and the Antinomies of Critical Theory. Modern Drama, v. 40, p. 86-99, 1997.

ROSE, Mark. Shakespearean Design. Harvard UP, 1974.

ROSE, Paul Lawrence. Frayn's "Copenhagen” Plays Well, at History's Expense. The Chronicle of Higher Education, May 5, 2000, B4-B6.

RYAN, Marie-Laure. Possible Worlds, Artificial Intelligence, and Narrative Theory. Bloomington: Indiana UP, 1991.

SHAW, George Bernard. Saint Joan. Ed. Stanley Weintraub. Bobbs-Merrill, 1971.

STOPPARD, Tom. Squaring the Circle. Faber, 1984

STRINDBERG, August. Open Letters to the Intimate Theater. Translated by Walter Johnson. U of Washington P, 1967.

WHITESIDE, Anna. Theories of Reference. In: WHITESIDE, Anna; ISSACHAROFF, Michael. On Referring in Literature. Bloomington: Indiana UP, 1987. p. 175-204.

WIKANDER, Matthew H. The Play of Truth and State: Historical Drama from Shakespeare to Brecht. Johns Hopkins UP, 1986.

Recebido: 13 de fevereiro de 2017

Aprovado: 20 de março de 2017

Contato: richb@umd.edu

\footnotetext{
5 Here I am equating narrative fiction with enacted drama; I should note that this does not always hold, since the two terms do not correspond to each other perfectly. It is prose narrative that can be fictional or nonfictional; similarly drama can be fictional or, in rare cases, nonfictional. This is the status of the documentary drama, which is held to the same standards of verisimilitude as a nonfictional work of narrative prose.
} 